\title{
The brash and the soft-spoken: Lobbying styles in a transatlantic comparison
}

\author{
Cornelia Woll \\ Sciences Po Paris and Max Planck Institute for the Studies of Societies Cologne, Sciences Po, \\ 27 rue Saint Guillaume, 75007 Paris, France. \\ cornelia.woll@sciences-po.fr
}

Executive Summary Lobbying on both sides of the Atlantic has experienced a considerable boom in the last 50 years and one could be led to believe that the two industries look increasingly alike. Lobbyists have become highly professionalized and master a multitude of venues and levels of political authority. Direct representation of companies or other stakeholders co-exists with associational representation in both Washington DC and Brussels, even though peak associations play a greater role in Europe. The use of some instruments is different, however, in particular financial contributions and legal tactics, which are central in the United States (US) and much less common in the European Union (EU). What is more, observers of lobbying in the US and the EU have noted the markedly different lobbying styles: frequently aggressive advocacy approach in the US and a more consensus-oriented informational lobbying in the EU. While US groups and lobbyists oftentimes defend their immediate interest by trying to exert pressure on public officials, EU representatives seem to be more soft-spoken in their approach and are said to work in a more constructive manner with bureaucratic and political representatives. After developing a description of what makes up the respective styles, this article discusses cultural and institutional explanations cited in the literature. Rather than seeing lobbying styles as culture traits, it discusses the institutional constraints affecting lobbying behavior. In particular, the passage rate of proposals, the fragmentation of public media, the electoral structure and the transparency of political negotiations create different incentive structures in the US and the EU. However, lobbying styles are more than the cumulative effect of these different elements. They are linked to the nature of the political system, of which the institutional constraints are a reflection. The US, a fully established federal system, relies on majority decision-making. This creates an adversarial culture and 'winner-takes-all-politics'. The EU, by contrast, functions as a complex intergovernmental system with a high degree of supranational centralization. The resulting tension between integration and inter-state bargaining creates a system that relies on consensus-building. In this context, the access of private actors to supranational institutions depends on their contribution to the creation of problem-solving policy approaches. As long as the EU has to rely on the acceptance of its policy outputs for its legitimacy, we are bound to find many individual

(C) 2012 Macmillan Publishers Ltd. 2047-7414 Interest Groups \& Advocacy Vol. 1, 2, 193-214 www.palgrave-journals.com/iga/ 
mechanisms that will trigger a more soft-spoken lobbying style in the EU. The differences between the US and the EU styles will thus appear as instances of a particular political culture, even though they are based on a range of institutional mechanisms, which are in turn a consequence of the construction of the respective political system. In conclusion, the article discusses the implications of this distinction for understanding change over time.

Interest Groups \& Advocacy (2012) 1, 193-214. doi:10.1057/iga.2012.10

Keywords: lobbying styles; culture; opportunity structures; EU; US

Tracking the participation of private interests in governmental policy making has been at the heart of policy analyses for almost a century. The two biggest lobbying industries, the United States (US) and the European Union (EU) have been extensively studied, but the vast literatures have developed in relative isolation from each other (Lowery et al, 2008). Only recently, scholars have called for more systematic comparison between the two (Thomas, 2004; McGrath, 2005; Mahoney, 2008; Mahoney and Baumgartner, 2008). Although much of the activities and environment of interest groups in the two settings appear to be comparable, the lobbying styles in the US and the EU are quite distinct (EurActiv, 2005). In contrast to the typically (but not exclusively) aggressive lobbying methods that one can observe in the US, lobbying in the EU is supposedly much more consensual and essentially based on the exchange of information. In order to underline this contrast, some authors have even gone so far as to describe the groups that engage in the US process as 'pressure groups', while the ones active in the EU are referred to as 'interest groups' (for example, Jacomet, 2000). For lobbyists, mastering this difference can be crucial, since adopting an approach that is ill fit for a particular setting can jeopardize the political objectives.

It is thus important to understand how and why lobbying differs in the US and the EU. By examining the general phenomenon of 'lobbying' rather than all the activities of 'interest groups', the article will focus on activities by which non-governmental actors seek to influence the political process rather than the ways in which they mobilize their members or more generally the system of private-public relationships that may exist in a particular country (for discussion see Baumgartner and Leech, 1998; Lowery et al, 2008). Concentrating on 'lobbying styles' allows examination of the behavior lobbyists adopt in their interactions with government: that is, it analyzes not only choices of venue and instruments, but also the manner in which the lobbyists puts forward their concerns. The article elaborates on the differences in lobbying styles in Washington DC and Brussels and sets out to explain them. Existing 
surveys of lobbying styles rarely focus on explaining their origins from a comparative perspective (but see Milbrath, 1963; Rosenthal, 1993; Van Schendelen, 1993; McGrath, 2005; Van Schendelen, 2011), although some authors have examined the transfer of styles from one setting to the other (Coen, 1999; Thomas, 2002; Thomas and Hrebenar, 2009).

Those interested in the reasons for distinct styles cite both cultural differences and institutional constraints (cf. Thomas, 2002). From a cultural perspective, lobbying styles are the consequence of political traditions and understandings of what is legitimate advocacy behavior. McGrath (2005, p. 149), for example, insists that both 'systems have particular cultural norms and values which can shape lobbying practices'. Are Europeans just more discreet, issue-specific and consensus-loving than their American counterparts? On the basis of a rigorous empirical comparison, Mahoney (2008) and others counter this interpretation and argue instead that institutional differences are responsible for the divergent behavior. Concentrating on individual institutional mechanisms, Mahoney provides a list of reasons for the particular EU lobbying style. While instructive for understanding the specific constraints lobbyists have to deal with, arguably such a list-based approach obscures more fundamental reasons for institutional variation and thus lobbying styles.

This article argues that lobbying styles are tied to the nature of the political system. The US is a fully established federal system. It is built around majority decision-making, but due to the representational rules, in particular in the Senate, even minorities can win legislative battles, without attempting a compromise. This creates an adversarial culture and 'winner-takes-all-politics', as Hacker and Pierson (2011) have recently argued. The legal system, dominated by lawyers rather than judges, reinforces this tendency and has been labeled 'adversarial legalism' (Kagan, 2003). The EU, by contrast, functions as a complex intergovernmental system with a high degree of supranational centralization. The resulting tension between integration and inter-state bargaining creates a system that relies on consensus-building (Kleine, forthcoming). In this context, the access of private actors to supranational institutions depends on their contribution to the creation of problem-solving policy approaches. As long as the EU has to rely on the acceptance of its policy outputs for its legitimacy (Scharpf, 1999), we are bound to find many individual mechanisms that will trigger a more soft-spoken lobbying style in the EU, which Coen $(1999,2002)$ has called 'European credibility'. The difference between the US and the EU styles will thus appear as a particular political culture, even though it is based on a range of institutional mechanisms, which are in turn a consequence of the construction of the respective political system.

The article divides into three parts. A first section presents the differences in lobbying in the US and the EU. The next section turns to cultural and institutional explanations, focusing in particular on the individual institutional 
mechanism behind the differences. A subsequent section draws these lessons together and provides more general institutionalist argument for the distinct political cultures. The conclusion spells out the implications of the findings for lobbying and institutional development.

\section{Lobbying in a Transatlantic Comparison}

Attempts to exert political influence can reflect a myriad of different strategies. Private actors can either try to influence the policymaker directly, through personal contacts, consultation procedures, written statements or financial contributions, or they can seek to influence public opinion in order to change the position of policymakers, for example, through media campaigns, law suits or grassroots strategies. Such indirect influence is referred to as outside lobbying, opposed to the inside lobbying of those that have direct access to the policymakers (Maloney et al, 1994; Kollman, 1998). Even though the lobbying industry in the EU has expanded considerably in the last 20 years and appears to be largely comparable to the US, important differences remain between the two. The following section will review differences in development and style.

\section{US lobbying: Lawyers and money?}

The US is generally considered the birthplace of professional lobbying as a political phenomenon, and the wealth of studies testifies to the fact that it has become a ubiquitous part of US politics at all levels of decision-making (for systematic surveys see Milbrath, 1963; Heinz et al, 1993; Gray and Lowery, 1996; Baumgartner and Leech, 1998).

Despite the mistrust of special interest that dates back to Madison's Federalist Papers, lobbying is an accepted or endured political tradition in American politics. In fact, the right to communicate special interests is firmly anchored in the US constitution, where the First Amendment protects the right of the people to 'petition the government for redress of grievances'. Lobbying is considered part of such political participation and therefore is considered to constitute an element of free speech. However, observers quickly realized that not all interests present in society would be able to organize themselves to influence the political process, in particular these normative reservations expanded following Mancur Olson's (1965) work on collective action problems.

To preserve the right to participate while at the same limiting potential abuse and biased influence, regulation of lobbying in the US therefore tended to emphasize transparency, but shied away from heavy intervention. Rules on 
lobbying were considered in every Congress after 1911 but were not approved until 1946. The 1946 law aimed at disclosure, making lobbyists register their name and spending. After a report found the requirements to be completely ineffective in 1995, Congress approved a number of changes, most notably broadening the definition of lobbying, reinforcing the requirements and tightening lobbying from foreign interests. Only 10 years later, a scandal surrounding the lobbyist Jack Abramoff led to the 2006 Legislative Transparency and Accountability Act, which specified in great detail what kind of gifts were considered as inappropriate. ${ }^{1}$ The Honest Leadership and Open Government Act of 2007 continued to detail restrictions and disclosure requirements applying to public officials. Through this recent series of reforms, the US is today one of the most tightly regulated lobbying industries in the world (Chari et al, 2010).

Increasing regulation reflects the growth of lobbying over the years, both by interests groups, firms and professional lobbyists. Associations representing special interests predate direct representation and their number grew remarkably in the last 50 years. In 1955, there were about 5000 national associations; in 1975, there were 13000; by 2000 there were more than 23000 national associations - along with more than 64000 regional, state and local associations. A large number of these associations represent economic interests. Nonetheless, companies increasingly choose to have a direct representation as well: between the 1920s and today, their number of firms that have permanent offices in Washington DC has climbed from 1 to over 600 (Baumgartner and Leech, 1998, pp. 102-105; Herrnson et al, 1998, pp. 7-9). As the maintenance of government affairs offices is costly, the vast majority of US companies do not maintain offices in Washington, but instead chose to hire a representative from a lobbying firm or a law firm specialized in public affairs. This practice is very common in the US and almost gained mythical status through literature and films. ${ }^{2}$ However, unlike popular impressions, employing a 'hired gun' is only common for companies that do little lobbying on a regular basis or companies that want to tackle a particularly difficult legal matter. Companies that interact regularly with the US government tend to have in-house representatives, even though they might employ both (Heinz et al, 1993, p. 65). According to the Center for Responsive Politics, a think tank publishing the most comprehensive data on lobbying activities and expenditures in the US, over 12000 registered lobbyists - from associations, firms and lobbying firms - actively lobbied at the federal level in 2011, spending a total of US $\$ 2.46$ billion in campaign contributions and donations. ${ }^{3}$

Financial contributions are probably the most noted and distinctive aspect of US lobbying activities. They can be divided into three categories: gifts, 'soft money' and campaign financing. While gifts, dinners, theatre trips and vacations used to be common, honoraria for lawmakers have been abolished and 
all but nominal gifts are prohibited. 'Soft money' refers to donations made to political parties, not to the candidates, supposed to be used only for partybuilding activities, not for direct campaign support. Of all forms of financial contributions, campaign financing has received the most attention. Unlike individuals, companies and labor unions cannot make direct contributions, but are required to form Political Action Committees (PACs) through which they can contribute (Herrnson, 1998; Rozell and Wilcox, 1999). Both hard and soft financial contributions are well documented. Not only do PACs need to register according to issues and contributions, there are also several encyclopedias and web sites who collect and publish this information. ${ }^{4}$

Much of the lobbying activities are carried out by lawyers, not only because the job requires familiarity with the writing and interpretation of bills, but also because interest groups may rely on legal strategies to defend their cause. In the most high profile cases, interest groups file suits in state and federal court in the hope of overturning a law as unconstitutional. This strategy has been used by the National Association for the Advancement of Colored People, for example, which successfully challenged segregation laws. More commonly, groups can file complaints against public authorities, challenge changes in administrative rule making or write amicus curiae briefs to influence court cases when they are not parties to the suit. Still, the persistent threat of legal proceedings is common, and leads many observers to describe the Washington lobbying style as adversarial.

If money and legal affairs are the most noted aspects of lobbying in Washington DC, a survey of the allocation of time of government affairs representatives reveals that the most amount of daily work is spent elsewhere. ${ }^{5}$ A government affairs official spends about 30 per cent of her time on organization duties, which include informing the company about activities in the capital and organizing working groups or other activities. Sixty per cent of time is actually spent on federal policy issues, but most often, this refers to maintaining the contact with government official, going to meetings, following hearings or the work of subcommittees of Congress (Heinz et al, 1993, pp. 87-104). The daily work of Washington lobbyists thus seems much less glamorous than one might expect.

\section{EU lobbying: Expert knowledge and multi-level representation}

Although interest groups have been at the heart of early studies on the European project, the bulk of writing on EU lobbying followed the re-launch of integration in the mid-1980s. With the simultaneous growth of interest group participation at the supranational level, the most extensive number of studies of lobbying has revolved around new and old forms of interest repre- 
sentation in the EU (Kirchner, 1981; Greenwood et al, 1992; Van Schendelen, 1993; Bindi, 1994; Pedler and Van Schendelen, 1994; Aspinwall and Greenwood, 1998; Claeys et al, 1998). Systematic studies of lobbying are most often used as a means of understanding the new political structure that emerges and the system of governance it creates (Schmitter and Streeck, 1991; Mazey and Richardson, 1993; Kohler-Koch and Eising, 1999; Balme et al, 2002). More recent studies have investigated the strategies used by special interest to participate at the different policy levels, relying increasingly on large N-studies (cf. Woll, 2006; Coen, 2007; De Bièvre and Dür, 2007; Beyers et al, 2008).

In contrast to the US, political activities of private actors have traditionally been much more suspect in Europe. Especially, in France and the Southern European countries, interest groups seem to represent 'a deviation of the proper functioning of the State and the political system' (Offerle, 1994; Basso, 1997, p. 39). The representation of economic interests is carried out by associations and peak associations, who have a much more central standing in the political system of their home countries than their American counterparts.

The Commission estimates that more than 2600 interest groups are active in Brussels today, with a significant portion representing economic interests (Coen, 2002, p. 258). In the course of the last 25 years, economic interest representation evolved from associational representation only to include direct firm representation, most notably at the European level (Cowles, 1998; Coen, 1999). Between 1985 and 1997, more than 350 businesses decide to establish government affairs offices in Brussels and national peak associations increase the number of employees working on European affairs. All in all, the lobbying industry employs around 15000 people in Brussels, and has a budget of roughly 60-90 million euros (European Parliament, 2003). Five thousand of the lobbyists are officially registered by the European Parliament. ${ }^{6}$

The regulation of lobbying in the EU is much less developed than in the US. Early attempts in the late 1990s encouraged voluntary registration by lobbyists and public disclosure standards for members of parliament. To avoid further regulation, public affairs associations in Europe published codes of conduct for their members. In 2005, the Commission esteemed that these rules were insufficient and proposed the European Transparency Initiative, which sought to increase registration requirements, disclosure and ethics rules and standards for public officials (see Chari et al, 2010). Still, when compared with the reporting requirements in the US, European regulation is minimal.

This is in part due to different practices. Campaign contributions, for example, do not exist at the European level and in most European countries, political campaigns rely on public funding. In fact, financial contributions even go the other way: non-profit organizations representing interests that are structurally difficult to mobilize often receive money from the European 
Commission. By funding and sometimes even founding these associations, the European Commission seeks to balance out the breadth of interests that can be represented at the European level (Sanchez-Salgado, 2007; Mahoney and Beckstrand, 2011).

In addition to these general differences, most scholars note that there is a distinct 'European style' in the daily advocacy work, made up of at least two elements. First, this European style is marked by a less aggressive and more consensual approach to political participation. Cowles (1996, pp. 345-346; 1997, p. 128) illustrates this difference well in her account of the US reaction to a social directive proposed by the European Commission.

[The directive] provoked a great deal of anxiety among American [multinational companies] with no Brussels based representatives and little prior contact with the EU. Instead of calling on the EU Committee to represent their concerns, these US firms took matters in their own hands. Armed with a plane full of Washington lawyers, the companies descended upon Brussels to confront the Eurocrats. [...] The Washington approach was a public relations disaster. Appropriate for the confrontational style of lobbying common in the US, but inappropriate for the subtle Brussels approach. From 1981, the EU Committee undertook a great effort to re-establish the image of American businesses in Brussels.

Instead of confronting public officials, European lobbyists typically gain access through expert consultations. Advising the European Commission on technical policy matters has proven to be the most common and most successful mode of participation of societal actors of all kinds (Radaelli, 1995; Bouwen, 2002; Saurugger, 2002). While representatives have a chance to express their views on policy proposals, Commission officials, but also Members of the European Parliament (MAP), benefit from the technical expertise these actors can provide. The symbiosis between public officials and private interests in Europe thus hinges on the latter's constructive and informed participation.

European lobbyists also encounter difficulties when they try to adopt the US style, that is, a more aggressive mode of lobbying. An illustration is the lobbying campaign undertaken by the European oil refinery representation EUROPIA around the Auto-Oil Program of the EU. When the Commission first started working on a proposal to reduce pollution through motor vehicles in 1993, EUROPIA was able to develop a productive working relationship with the Commission to agree on the most cost effective way to reduce pollution (Corporate Europe Observatory, 1999). Once the European Parliament and later the Council rejected the Commission proposal, precisely because it seemed to be biased towards the interests of the oil industry, EUROPIA started a massive lobbying effort on the European Parliament who sought to tighten the standards to a 
higher level, arguing that the measure would lead to the end of oil refineries in Europe, which would ultimately costs the MEPs their job. In the debates, MEPs repeatedly refused to be bullied and suggested 'getting a hat and collecting money for the poor oil industry'. ${ }^{7}$ Ironically, the lobbying efforts might even explain the consensus of the European Parliament to tighten auto emission standards. According to an observer, the aggressive lobbying had an undesired result:

It completely backfired! [...] to the point where the guy who was the head of EUROPIA got sent to Africa [...]. They put another person and the next 5 years, this person worked really hard to try and build bridges again with everybody. ${ }^{8}$

For both the Commission and the European Parliament, a constructive approach is more important than arguments based on threats and pressure.

A second element of European lobbying is the multi-level approach lobbyists need to adopt to press for their cause. The competency division between the European Institutions and the difference between high-level politics - decided by the Council of Ministers or even the heads of government - and low-level politics the less politicized, bureaucratic work of the European Commission and amended by the European Parliament - require that interest representation employs a multitude of channels on any one particular issue. ${ }^{9}$ In contrast to the US, where multi-level representation becomes necessary in particular once a policy issue shift from the state to the federal level (or back), multi-level representation is necessary on all policy issues dealt with by the EU institutions.

Most scholars have noted the complex web of representation and the superposition of regional, national and European levels of interest organization (Greenwood et al, 1992; Teuber, 2001, p. 150; Eising, 2004). On any particular issue, the multitude of channels of representation may include direct representation, national peak associations, sectoral association, European umbrella organizations or other thematic European or transnational groups. The acknowledgement of a multi-level approach of interest representation is the most general conclusion of the studies of European lobbying. While this has been of considerable inspiration to theories of European governance (Kohler-Koch and Eising, 1999; Marks and Hooghe, 2001), little has been done to evaluate the implications of this approach for the impact of groups on political decisions (for an exception, see Grande, 1996).

\section{Comparing US and EU lobbying}

The brief overview highlights the similarities and differences in lobbying in the US and the EU. Lobbying on both sides of the Atlantic has experienced 
a considerable boom in the last 50 years, which corresponded to the increase in the governmental activity in Washington DC and Brussels. Direct representation of companies co-exists with associational representation in both cases, even though peak association play a greater role in Europe and the multitude of channels is somewhat more complex in the EU, where several policy levels are often important for the same issue. Financial contribution and legal tactics, in turn, are central to US lobbying. By contrast, campaign financing is not possible in EU politics and the use of lawyers much less common for advocacy work in Brussels (see Bouwen and McCown, 2004).

However, the everyday practices of lobbying in both cases are comparable. During consultation and everyday contacts, US and EU lobbyists alike have to rely on providing expertise and information to defend their positions (Potters and Van Winden, 1990; Bennedsen and Feldmann, 2002). Yet, a more nuanced analysis indicates that even in the context of informational lobbying, lobbying styles are somewhat different in Washington DC and Brussels. While US groups and lobbyists oftentimes defend their immediate interest by trying to exert pressure on public officials, EU representatives often seem to be less determined and more soft-spoken in their approach.

Coen $(1998,1999)$ indicates that these two approaches correspond to the different role trust plays in the relationship between private interests and public officials. EU lobbying is much more rooted in long-term relationships and trust than is the case in the US. As Vogel (1996a, p. 11) points out for the case of business lobbyists, the relationship among firms trying to affect the government in the US is characterized by an 'adversary culture'. This contrast is something that many practitioners underline when they are asked about differences in work of lobbyists on both sides of the Atlantic. To cite an example, this British lobbyist tries to explain why lobbying plays a greater role in the US than they do in Brussels or London (McGrath, 2002):

In Washington, lobbying [...] is very specialized [...]. Therefore, if they are specialists it is much more natural that they should be putting the case. I think it might also simply have to do with the natural characteristics, for here people tend to be very reserved, polite, discreet, while Americans seem to be very brash and in your face.

These impressions highlight that there seems to be a difference in lobbying styles, despite all the similarities in lobbying tactics. Put differently, it is not what you do, it is how you do it. "No one expects the "full on" US style lobbying tactics to work in Europe; rather, we can expect an increasingly subtle style [...]', suggests Coen $(1999$, p. 41) in his analysis. To him, the European style is characterized by a 'low public profile' and being 'sophisticated', compared with the 'aggressive lobbying of Washington firms'. Thomas and Hrebenar (2009) 
underline that "unlike the situation in the US where "defensive lobbying" is a widely used tactic, it is not in the nature of EU lobbying to stop something, to kill it'. These characteristics are especially visible to practitioners and policymakers, who repeatedly underline differences, like a MEP who deplores the 'gangster style of American lobbyists' or an EU lobbyist who explains that 'in Brussels, you must learn to speak softly, softly', (Gardner, 1991, p. 63). Somehow, all analysts seem to agree that EU lobbying is less confrontational and consensus-oriented than US lobbying.

\section{Of Culture and Institutions}

What is the reason for this difference? While some authors refer to culture, the most developed arguments specify the institutional mechanisms behind lobbying choices. Rather than consider the two as competing approaches, the article will show that the individual mechanism are rooted in the respective set-ups of the two political systems, which in turn creates specific political cultures. Before developing this argument in the final section, it is useful to consider existing arguments about cultural and institutional origins of lobbying styles.

\section{Different cultures}

References to culture are common in the analyses of lobbying styles, although not very often specified. The most explicit link is made in the writing of Thomas (2002), who speaks of 'American and European lobbying cultures' and seemingly equates 'lobbying styles' with 'cultural norms' when he asks 'to what extent has the success and failure of American groups in the EU been achieved by using American-style techniques [...] or depended on adjusting to European cultural norms?' Similarly, he refers to the use of 'hired guns' and aggressive techniques as American 'cultural traits'. In her analysis of the work of the American Chamber of Commerce's work in Europe, Cowles (1994, p. 285) explains that the success of the group depended on adapting their lobbying tactic to being 'critical but constructive'. As one of her interviewees puts it, the goal was to combine the 'more technical input typical of American lobbying with the culture and experience of Europe'. McGrath (2002) underlines the 'legal/cultural' roots of lobbying differences between the US and Europe and cites a British lobbyist:

Until very recently, we didn't have the right to do anything. We were told what we weren't allowed to do, and that just characterized your approach [...]. That's why lobbying [in Britain] always had a dirty feel about it. 
According to this account, it seems that the role of interest groups in Europe is constrained not only by their actual legal rights, but also by the political traditions and normative perspectives on the role of private actors.

To some extent, the cultural argument seems to rest on an imprecision in the use of culture as an analytical concept. In many instances, "political cultures' is employed to cover all forms of procedures and ways of doing things that are specific to a given country or region. Quite often, the word 'culture' is helpful less for the academic who wrote the comparative studies, but for the practitioners he or she interviewed, as the citations above highlight. From the perspective of a lobbyist working in either Brussels or Washington DC, the concept permits to categorize all patterns of behavior that are different and country-specific.

It would be unfair to criticize these authors for an argument about political culture that they have never made explicitly. Even Thomas and Hrebenar (2009), who ask what role culture plays in shaping lobbying traditions, never really answer their question, but instead conclude that 'cultural and institutional factors overlap and in some ways may be inseparable'. In fact, one of the strongest criticisms of political culture as an analytical variable is that it is not clear whether culture is an effect or a cause of institutional development. ${ }^{10}$ Indeed, the recurring references to divergent traditions and political cultures are misleading to scholars interested in comparing the policy process of the US and the EU, because they posit that the ways by which private actors participate in their political systems are exogenously given. Considering the more specific institutional constraints weighing on lobbyists and analyzing the reasons for their existence helps to see that political culture is endogenous and can evolves with changes in the political systems. Before developing how this is possible, let us examine the institutional reasons for divergent lobbying styles.

\section{Institutional mechanism}

A growing literature examines the constraints and opportunities for private actors' participation, often regrouped under the label 'opportunity structure'. ${ }^{11}$ Mahoney (2008) has done this by directly comparing lobbying in Washington and Brussels. She highlights three institutional differences that condition advocacy work, to which a fourth one, centered on transparency, can be added. First, the likelihood of a policy proposal succeeding affects how interest groups position themselves. Second, media used to affect public opinion is integrated in the US and fragmented in Europe. Third, direct elections of policymakers affect their responsiveness to constituency interests. Finally, it is likely that transparency about the activities of interest groups is lower in the EU. 


\section{Passage rate of proposals}

In the US, a large number of legislative proposals get introduced each year in the House and the Senate, but the vast majority never becomes enacted. In the EU a proposal may take a long time, but eventually the majority of it may become adopted. The relationship between the life expectancy of a policy proposal and lobbying behavior is very straightforward. If a lobbyist can assume that a proposal will eventually become enacted, he or she should concentrate efforts on modifying it. If the majority of proposals never become enacted, an attempt to kill a proposal can actually be successful. In the US, Mahoney (2008, p. 64) finds that 306 laws were enacted in 2004 out of 2764 proposals, or inversely 2458 proposals have died. With a passage rate of only 11 per cent, it is indeed sensible not to invest too much time on modifying a proposal and to try and oppose it in its entirety. In the EU, the European Parliament can reject a proposal if the majority of MEPs vote against the proposal (that is, between 123 and 369 MEPs depending on the number of attendance). Likewise, the European Commission can withdraw legislation pending if it is no longer relevant, in conflict with the subsidiarity principle or if there is a lack of political will in the Council. With roughly 500 proposals initiated by the European Commission each year, somewhere between 30 and 100 are withdrawn each year (European Commission, 2007). Put differently, we can estimate that 80 per cent or more of all proposals will eventually be adopted. Adopting an aggressive strategy that aims to kill a policy initiative is thus simply much more risky in the EU.

\section{Media and public opinion}

The availability of media outlets that can reach an important part of a political constituency is a prerequisite for outside strategies that target public opinion. Diffusing political messages or creating a scandal is difficult in a polity that is culturally heterogeneous, made up of 27 member states and divided into 23 official languages. Even Internet strategies are hard to organize in a setting with 23 official languages. It is therefore difficult to imagine European interest group to function in ways similar to MoveOn.org in the US, for example, which heavily relies on the Internet for its advocacy work and has turned out to be crucial for the campaign financing of the Democratic Party. Likewise, organizing European-wide protest movements is a much more challenging, even if national protest movements begin to integrate across borders (Imig and Tarrow, 2001). Compared with the US, however, outside lobbying strategies are less of an alternative to inside lobbying.

\section{Direct elections}

In the US, the executive branch and members of Congress are keenly aware that they depend on constituency support for re-election. In the EU, the 
European Commission as an administration is shielded from electoral pressure and even the European Parliament is somewhat more sheltered, since election success often depends more on national politics than European issues - the so-called second-order election problem (for example, Marsh, 1998). However, the relationship between direct elections and interest group influence is less straightforward than one would imagine. One hypothesis would be that policymakers who depend on electoral support are simply more responsive to information about their constituencies, because they depend on their votes. Policymakers in the US should thus be more easily accessible and more easily pressured than their European counterparts, who should be less easily convinced to change their position on an issue. However, Mahoney's (2008) study shows that lobbyists in the EU also declare that they have successfully influence the policy process. What is more, the percentage of US lobbyists who claim to have attained none of their stated goals is higher in the US than in the EU (46 per cent and 39, respectively). In fact, lobbying in the US is an all-or-nothing game, while EU policy making tends towards compromise, where most stakeholders achieve some of their goals, but few obtain all they asked for. Put differently, lobbyists are on average more successfully in the EU than in the US, but fewer of them attain exactly what they want (see also Mahoney, 2007).

\section{Transparency}

As a result of underdeveloped regulation of lobbying and the fragmentation of policy authority in the EU, transparency is lower. In the US, all consultations are available on the Internet and lobbyists have to declare in great details their activities, work relationships and contributions. In addition, information about hearings, meetings, grant applications, administrative orders, proposed rules and regulations and other policy documents detailing lobbying activities are available online the Federal Register, which allows following a policy process from the very beginning and through a wealth of documents, by topic or agency. ${ }^{12}$ In recent years, the EU tried to adopt similar procedures through the so-called 'Transparency Initiative', which also created a Transparency Register in 2011. ${ }^{13}$ However, the participation of lobbysts in the European register is voluntary and so far, the initiative only covers the European Commission and the European Parliament, not the European Council and other regulatory agencies.

As Naurin (2004) has demonstrated, differences in transparency greatly affect lobbying behavior in a way that might be counter intuitive. Lobbyists do not necessarily behave 'better' when their activities are public, even though transparency may decrease outright corruption. But transparency also influences how much lobbyists feel accountable to the members or the groups they represent. Government representatives of associations or firms have a dual 
role of trying to influence the policy process and informing the group they work for of their progress. ${ }^{14}$ When transparency is low, representatives can be constructive and willing to compromise, because they do not fear to be sanctioned by their members or clients for going beyond their mandate (see also Stasavage, 2004). Such cooperation may allow continued influence, but decreases the likelihood of obtaining what one set out for in the beginning. When transparency is high, by contrast, a representative has little choice but to repeat the very narrow policy stance that was internally negotiated by the collective or firm he or she represents. High transparency thus reduces the room for cooperation among multiple stakeholders.

\section{The Nature of the Political Systems}

Considering the individual institutional mechanism is helpful for understanding the daily constraints weighing on lobbyists. However, the difference between US and EU styles is more than just the addition of these individual components. At a more fundamental level, the institutional differences are rooted in the set-up of the political systems in the US and the EU. Although both constitute federal systems and are therefore comparable, the US is a nation-state and the EU a complex form of inter-state cooperation.

This final section examines the two different political systems from a birds-eye perspective to make a more general argument. Focusing on the specificities of the EU, the article argues that one needs to understand that its survival depends on its ability to reconcile the conflicting positions of its member countries, and therefore its domestic stakeholders. Scharpf (1999) has called this phenomenon 'output legitimacy', as opposed to 'input legitimacy', which gives a polity credibility through the functioning of its political institutions. As a nation-state, the US has a fully functioning federal system that does not need to produce 'good policies' in order to be legitimate. Quite on the contrary, Hacker and Pierson (2011) have recently criticized that US politics is even able to produce policies that only benefit a small minority without visible effects for its continuation. The discussion about the reasons for this situation are beyond the scope of this paper, but it suffices to acknowledge that US politics in general is marked by an adversarial culture, where different stakeholders try to win out over others, with an increasing polarization of political parties in recent years (McCarty et al, 2006).

By contrast, policy making in the EU needs to rely on compromises. Since policy authority is shared in the EU and not divided as in the US, policy making in Europe is bound by a de facto consensus requirement. Even where the supranational institutions, in particular the European Commission and the European Parliament, have formal policy authority, a wide range of informal 
mechanisms exist to ensure that member states retain control over policy outputs. The reason for these informal governance mechanisms is that member states want to shelter domestic stakeholders from concentrated costs that could arise through integration, as Kleine (forthcoming) demonstrates. Failure to reach consensus may lead to blockage, so that the European Institutions have a strong incentive to achieve problem solving rather than bargaining style policy negotiations.

This implies, on the one hand, that domestic stakeholder will be represented through their elected governments. On the other hand, it creates a constraint for those interest groups and lobbyists that seek to work with the supranational institutions. As Bouwen (2002) has argued, lobbying in the EU is marked by an exchange logic, where lobbyists gain access in exchange of specific types of information. In their search for expert advice, the European Institutions will privilege those interest representatives that contribute to the creation of a problem-solving situation.

Interest groups thus have an incentive to formulate their demands in constructive terms that do not inhibit problem-solving situations, especially when they are participating in early stages of the agenda-setting process in consultations with the European Commission (for discussion Héritier, 1999; Bouwen, 2004). As interest groups cannot rely on electoral pressure to insure that they will be heard, they have to adapt to the institutional objectives of their counterparts. As Grande (1996, p. 328) has argued with reference to Robert Putnam's two-level games, preferences 'outside the win set of joint negotiations have no chance of being recognized'. This mirrors a fundamental proposition Scharpf et al (1976, p. 41) has made about the systems of joint decision-making: 'in the case of interest conflicts between general and special interests, we should expect a neglect of special interests for institutional reasons'. As Coen (1999, p. 38) points out for the EU Commission, 'officials have had to start to restrict access to those interests that it perceives to be its natural "issue partners" and that exhibit positive European credentials'. The lack of direct elections in the EU does therefore not prohibit private actors from influencing policymakers and public officials. However, it introduces a selection procedure that special interests have to adapt to in order to be successful.

In the US, in turn, access restriction seemingly creates increased competition for the 'better' or 'effective product' (Vogel, 1996b): lobbyists have to be better trained, more informed, louder and more insistent than their competitors. Contrary to the EU, the US system allows for bargaining, which creates a highly competitive political market that puts individual policy actors in a defensive position. Disagreement is an acceptable outcome (Scharpf, 1988, p. 312), and will not have any effect on the lobbyists future chances of being consulted. 
The institutional arrangement in the EU thus facilitates long-term and trustbased relationships, where unconstructive contributions can be sanctioned (Coen, 2007, p. 335). This means that lobbyists and associations have a strong incentive to formulate their policy demands in constructive terms, making reference to pan-European goals and principles rather than their most immediate interests. The demand by the European Institutions for expertise and the special interests desire to gain access by supplying the desired information creates a trade off. As Broscheid and Coen (2003, p. 167) underline, lobbyists can press for their most preferred policy or cooperate more fully with the institutional search for a compromise. Although the second option might bring them away from their desired outcome, it will assure greater continued access to the policy process. The question for a European lobbyist is therefore just how much they are willing to compromise in order to have a chance to continue influencing a policy proposal.

To return to the institutional mechanisms highlighted in the preceding section, the high passage rate of proposals, the lack of integrated media and the ambiguous effect of second-order elections are all elements of the incomplete integration of the political system in the EU. Likewise, transparency requirements increase not only the public visibility of lobbying activity, but also of interstate compromise, which some Member States might not have an interest in. We should therefore expect transparency requirement to remain somewhat different from the US, despite the recent trend toward convergence.

\section{Conclusion}

To summarize, the aggressive Washington lobbying style and the consensusoriented style of European lobbying are the results of the political arrangements in each political system. In the US, private actors can use legal strategies and intervene in the legislative process with the intention to reverse a law or kill a proposal. In the EU, the lack of electoral pressure and the ensuing discretion policy actors have to ignore stakeholders that do not help them to advance on their institutional objectives creates incentives to be constructive and compromise-oriented in order to build long-term relationships built on trust. Moreover, the low level of transparency allows the representatives that are actually involved in policy development to accept compromises that would be difficult to defend under full disclosure of negotiation details. Mastering these different institutional logics is a prerequisite for lobbying success and numerous anecdotes illustrate that aggressive lobbying can be counterproductive in the European Union (for example, Woll, 2009).

However, lobbying is unlikely to change if one or two of the institutional mechanisms listed evolve. What become clear is lobbying styles are in fact the consequences of two fundamentally different political systems. Although both 
the US and the EU constitute federal systems and are therefore comparable, one is a nation-state and the other a form of inter-state cooperation. Understanding the consequence of this more basic difference helps to see that we should not overestimate the importance of each individual mechanism taken by itself. Since individual elements are part of the more general set-up, we might, for example, expect that changes in one can be off-set by similar mechanisms elsewhere. Put differently, as long as the fundamental tensions remain, we will continue to see persistent differences in lobbying styles, even if one or two of the mechanisms highlighted above were to evolve. A grasp of the general reasons behind the development of different political cultures thus highlights under what circumstances we might expect convergence between the different lobbying styles.

Put differently, speaking softly is not a cultural trait of European lobbyists, it is a rational choice to attempt continued influence over a policy proposal. However, the institutional bias toward compromise is a more fundamental characteristic of the EU set-up and it is fair to say that this create a political culture that is less adversarial than in the US.

\section{Acknowledgements}

The article has benefitted from discussion at the Princeton Workshop on European Integration and at the EUSA Conference in Austin, Texas. I would like to thank all participants and Deniz Aksoy, Emiliano Grossman, Irina Michalowitz, Nils Ringe and two anonymous reviewers for their helpful remarks and suggestions. Jane Mansbridge and Mareike Kleine have contributed significantly to the current version of this article and I am grateful for their interest and suggestions.

\section{Notes}

1 Jack Abramoff and 21 persons were found guilty in the corruption scandal revolving around the defense of Indian casino interests. Besides the actual felonies for which Abramoff was convicted (conspiracy, fraud and tax evasion), the scandal also revealed the existence of perfectly legal but questionable activities, which the 2006 Act tried to address.

2 One series concerns the daily life of Washington lawyers named after the street where most legal consulting firms are located: 'K-Street'.

3 www.opensecrets.org/lobby/index.php.

4 See, for example, Ness (2000). The website www.opensecrets.org offers a complete list of publications and the figures of money collected in the last 15 years, using the official data published by the Federal Election Commission and other sources.

5 This does not apply to hired legal consultants, who do spend the majority of their time on legal affairs (Heinz et al, 1993, p. 88). 
6 Figure communicated by the Association of Accredited Lobbyists to the European Union, see www.aalep.eu.

7 The efforts, led by a large number of lobbyists who contacted every single MEP working on the issue, were so massive that MEPs from every party federation complained on the debate floor of being 'besieged' by lobbyists who 'wished to blame Parliament for the structural problems there might consequently be in this sector of industry'. Kronberger (NI) and Hautala (V) 'Motor vehicle emissions' Debates of the European Parliament, Sitting of Tuesday, 15 September 1998; and Lange (PSE), Air pollution by motor vehicles' Debates of the European Parliament, Sitting of Tuesday, 17 February 1998 available at www.europarl.eu.int/ plenary/default_en.htm.

8 Interview with an energy consultant, Brussels, 16 February 2005, carried out by Nils F. Ringe, whom I thank for bringing this incident to my attention.

9 On the distinction between high- and low-level politics, see Peterson and Bromberg (1999).

10 For an overview of the discussion on political culture, see Dalton (1996).

11 The term political opportunity structure refers to specific configurations of resources, institutional arrangements and historical precedents that facilitate or constrain the political participation of non-governmental actors.

12 See www.federalregister.gov.

13 europa.eu/transparency-register/index_en.htm.

14 With respect to associations, Schmitter and Streeck (1999) have termed the dynamics created by external tasks the 'logic of influence' and the dynamics created by internal maintenance 'logic of membership'.

\section{References}

Aspinwall, M. and Greenwood, J. (eds.) (1998) Collective Action in the European Union: Interests and the New Politics of Associability. London: Routledge.

Balme, R., Chabanet, D. and Wright, V. (eds.) (2002) L'action Collective en Europe. Paris, France: Presses de Sciences Po.

Basso, J. (1997) Les groupes d'intérêt, les groupes de pression et le fonctionnement de la démocratie en société civile européenne. L'Europe en formation 303(Winter): 39-51.

Baumgartner, F.R. and Leech, B.L. (1998) Basic Interests: The Importance of Groups in Politics and in Political Science. Princeton, NJ: Princeton University Press.

Bennedsen, M. and Feldmann, S.E. (2002) Lobbying legislatures. Journal of Political Economy 110(4): 919-946.

Beyers, J., Eising, R. and Maloney, W. (2008) Researching interest group politics in Europe and elsewhere: Much we study, little we know. West European Politics 31(6): 1103-1128.

Bindi, F.M. (1994) The role of eurogroups in the EU decision-making process. PhD dissertation, European University Institute.

Bouwen, P. (2002) Corporate lobbying in the European Union: The logic of access. Journal of European Public Policy 9(3): 365-390.

Bouwen, P. (2004) Exchanging access goods for access: A comparative study of business lobbying in the European Union institutions. European Journal of Political Research 43(3): 337-369.

Bouwen, P. and McCown, M. (2004) Lobbying versus litigation: Political and legal strategies of interest representation in the European Union. Journal of European Public Policy 14(3): 422-443.

Broscheid, A. and Coen, D. (2003) Insider and outsider lobbying in the European Commission. European Union Politics 4(2): 165-189.

Chari, R.S., Hogan, J. and Murphy, G. (2010) Regulating Lobbying: A Global Comparison. Manchester, UK: Manchester University Press. 
Claeys, P.-H., Gobin, C., Smets, I. and Winand, P. (eds.) (1998) Lobbyisme, pluralisme et intégration européenne. Brussels, Belgium: Presses interuniversitaires européennes.

Coen, D. (1998) The European business interest and the nation state: Large-firm lobbying in the European Union and member states. Journal of Public Policy 18(1): 75-100.

Coen, D. (1999) The impact of U.S. lobbying practice on the European business-government relationships. California Management Review 41(4): 27-44.

Coen, D. (2002) Business interests and European integration. In: R. Balme, D. Chabanet and V. Wright (eds.), L'action collective en Europe. Paris, France: Presses de Sciences Po, pp. 255-278.

Coen, D. (2007) Empirical and theoretical studies in EU lobbying. Journal of European Public Policy 14(3): 333-345.

Corporate Europe Observatory. (1999) The two faces of EU transport policy. Corporate Europe Observer, 3.

Cowles, M.G. (1994) The politics of big business in the European community: Setting the agenda for a new Europe. PhD dissertation, American University.

Cowles, M.G. (1996) The EU committee of amcham: The powerful voice of American business in Brussels. Journal of European Public Policy 3(3): 339-358.

Cowles, M.G. (1997) Organising industrial coalitions: A challenge for the future? In: H. Wallace and A. Young (eds.) Participation and Policy-Making in the European Union. Oxford: Clarendon Press.

Cowles, M.G. (1998) The changing architecture of big business. In: J. Greenwood and M. Aspinwall (eds.) Collective Action in the European Union: Interests and the New Politics of Associability. London: Routledge.

Dalton, R.J. (1996) Comparative politics: Micro-behavioral perspectives. In: R.E. Goodin and H.-D. Klingemann (eds.) A New Handbook of Political Science. Oxford: Oxford University Press, pp. 336-352.

De Bièvre, D. and Dür, A. (2007) Interest group influence on policymaking in Europe and the United States. Journal of Public Policy 27(1): 1-12.

Eising, R. (2004) Multilevel governance and business interests in the European Union. Governance 17(2): 211-246.

EurActiv. (2005) EU and US approaches to lobbying. http://www.euractiv.com/pa/eu-us-approacheslobbying/article-135509, accessed 29 August 2005.

European Commission. (2007) Better Lawmaking 2006. COM (2007) 286.

European Parliament. (2003) Lobbying in the European Union: Current rules and practices. AFCO 104 EN.

Gardner, J.N. (1991) Effective Lobbying in the European Community. Deventer, the Netherlands: Kluwer Law.

Grande, E. (1996) The state and interest groups in a framework of multi-level decision-making: The case of the European Union. Journal of European Public Policy 3(3): 318-338.

Gray, V. and Lowery, D. (1996) The Population Ecology of Interest Representation: Lobbying Communities in the American States. Ann Arbor, MI: The University of Michigan Press.

Greenwood, J., Grote, J. and Ronit, K. (eds.) (1992) Organized Interests and the European Community. London: Sage.

Hacker, J.S. and Pierson, P. (2011) Winner-Take-All Politics: How Washington Made the Rich Richer - And Turned Its Back on the Middle Class. New York: Simon \& Schuster.

Heinz, J.P., Laumann, E.O., Nelson, R.L. and Salisbury, R.H. (1993) The Hollow Core: Private Interests in National Policy Making. Cambridge, MA: Harvard University Press.

Héritier, A. (1999) Policy-Making and Diversity in Europe: Escaping Deadlock. Cambridge, UK: Cambridge University Press.

Herrnson, P. (1998) Interest groups, PACs and campaigns. In: P. Herrnson, R. Shaiko and C. Wilcox (eds.), The Interest Group Connection. Chatham, NJ: Chatham House Publishers, pp. 15-37.

212 (C) 2012 Macmillan Publishers Ltd. 2047-7414 Interest Groups \& Advocacy Vol. 1, 2, 193-214 
Herrnson, P., Shaiko, R. and Wilcox, C. (eds.) (1998) The Interest Group Connection: Electioneering, Lobbying, and Policymaking in Washington. Chatham, NJ: Chatham House Publishers.

Imig, D.R. and Tarrow, S.G. (2001) Contentious Europeans: Protest and Politics in an Emerging Polity of Governance in Europe. Lanham, MD: Rowman \& Littlefield.

Jacomet, D. (2000) Les stratégies d'entreprises face aux politiques publiques: le lobbying des producteurs occidentaux et la politique commerciale internationale dans le textile-habillement. PhD thesis, Université Paris IX - Dauphine.

Kagan, R. (2003) Adversarial Legalism: The American Way of Law. Cambridge, MA: Harvard University Press.

Kirchner, E.J. (1981) The Role of Interest Groups in the European Community. Aldershot, UK: Gower Publications.

Kleine, M. (forthcoming) Making Cooperation Work. Informal Governance in the European Union and Beyond. Ithaca, NY: Cornell University Press.

Kohler-Koch, B. and Eising, R. (1999) The Transformation of Governance in the European Union. London: Routledge.

Kollman, K. (1998) Outside Lobbying: Public Opinion and Interest Group Strategies. Princeton, NJ: Princeton University Press.

Lowery, D., Poppelaars, C. and Berkhout, J. (2008) The European Union interest system in comparative perspective: A bridge too far? West European Politics 31(6): 1231-1252.

Mahoney, C. (2007) Lobbying success in the United States and the European Union. Journal of Public Policy 27(1): 35-56.

Mahoney, C. (2008) Brussels versus the Beltway: Advocacy in the United States and the European Union. Washington DC: Georgetown University Press.

Mahoney, C. and Baumgartner, F.R. (2008) Converging perspectives on interest group research in Europe and America. West European Politics 31(6): 1253-1273.

Mahoney, C. and Beckstrand, M. (2011) Following the money: European Union funding of civil society organizations. Journal of Common Market Studies 49(6): 1339-1361.

Maloney, W.A., Jordan, G. and McLaughlin, A.M. (1994) Interest groups and public policy: The insider/outsider model revisited. Journal of Public Policy 14(1): 17-38.

Marks, G. and Hooghe, L. (2001) Multilevel Governance and European Integration. Lanham, MD: Rowman and Littlefield Publishers.

Marsh, M. (1998) Testing the second-order election model after four European elections. British Journal of Political Science 28(3): 591-607.

Mazey, S. and Richardson, J. (eds.) (1993) Lobbying in the European Community. Oxford: Oxford University Press.

McCarty, N., Rosenthal, H. and Poole, K.T. (2006) Polarized America: The Dance of Ideology and Unequal Riches. Cambridge, MA: MIT Press.

McGrath, C. (2002) Comparative lobbying practices: Washington, London, Brussels. In Annual Conference of the Political Studies Association. Aberdeen.

McGrath, C. (2005) Lobbying in Washington, London and Brussels: The Persuasive Communication of Political Ideas. Lewiston, NY: Edwin Mellen Press.

Milbrath, L.W. (1963) The Washington Lobbyists. Chicago, IL: Rand McNally.

Naurin, D. (2004) Dressed For Politics: Why Increasing Transparency in the European Union Will Not Make Lobbyists Behave Any Better Than They Already Do. Department of Political Science, Göteborg, Sweden: Göteborg University.

Ness, I. (ed.) (2000) Encyclopedia of Interest Groups and Lobbyists in the US. Armonk, NY: M.E. Sharpe.

Offerle, M. (1994) La sociologie des groupes d'intérêt. Paris, France: Montchrestien.

Olson, M. (1965) The Logic of Collective Action: Public Goods and the Theory of Groups. Cambridge, MA: Harvard University Press. 
Pedler, R.H. and Van Schendelen, M.P.C.M. (eds.) (1994) Lobbying in the EU: Companies, Trade Associations and Issue Groups. Aldershot, UK: Dartmouth.

Peterson, J. and Bromberg, E. (1999) Decision-Making in the European Union. London: Macmillan Press.

Potters, J. and Van Winden, F. (1990) Modelling political pressure as transmission of information. European Journal of Political Economy 6(1): 61-88.

Radaelli, C. (1995) The role of knowledge in the policy process. Journal of European Public Policy 2(2): 159-183.

Rosenthal, A. (1993) The Third House: Lobbyists and Lobbying in the States. Washington DC: CQ Press.

Rozell, M.J. and Wilcox, C. (1999) Interest Groups in American Campaigns: The New Face of Electioneering. Washington DC: A Division of Congressional Quarterly.

Sanchez-Salgado, R. (2007) Comment l'Europe construit la société civile. Paris, France: Dalloz-Sirey.

Saurugger, S. (2002) L'expertise: un mode de participation des groupes d'intérêt au processus décisionnel communautaire. Revue Française de Science Politique 52(4): 375-403.

Scharpf, F.W. (1988) The joint-decision trap. Public Administration 66: 239-278.

Scharpf, F.W. (1999) Governing in Europe: Effective and Democratic? Oxford: Oxford University Press.

Scharpf, F.W., Reissert, B. and Schnabel, F. (1976) Politikverflechtung: Theorie und Empirie des kooperativen Föderalismus in der Bundesrepublik. Regensburg, Germany: Scriptor Verlag.

Schmitter, P. and Streeck, W. (1991) From national corporatism to transnational pluralism: Organized interests in the single European market. Politics and Society 19(2): 133-152.

Schmitter, P.C. and Streeck, W. (1999) The organization of business interests: Studying the associative action of business in advanced industrial societies. MPIfG Discussion Paper 99/1.

Stasavage, D. (2004) Open-door or closed-door? Transparency in Domestic and International Bargaining 58(4): 667-703.

Teuber, J. (2001) Interessenverbände und Lobbying in der Europäischen Union. Frankfurt, Germany: Peter Lang.

Thomas, C.S. (2002) U.S. interest groups operating in the European Union: Is there a transatlantic lobbying culture? In: Transatlantic Studies Association. Scotland, UK: Dundee University.

Thomas, C.S. (ed.) (2004) Research Guide to U.S. and International Interest Groups. Westport, CT: Praeger.

Thomas, C.S. and Hrebenar, R.J. (2009) Comparing lobbying across liberal democracies: Problems, approaches and initial findings. Journal of Comparative Politics 2(1): 131-142.

Van Schendelen, M.P.C.M. (ed.) (1993) National Public and Private EC Lobbying. Aldershot, UK: Dartmouth.

Van Schendelen, R. (2011) More Machiavelli in Brussels: the Art of Lobbying in the EU. Amsterdam, the Netherlands: Amsterdam University Press.

Vogel, D. (1996a) Kindred Strangers: The Uneasy Relationship between Business and Politics in America. Princeton, NJ: Princeton University Press.

Vogel, D. (1996b) The study of business and politics. California Management Review 38(3): 146-165.

Woll, C. (2006) Lobbying in the European Union: From Sui Generis to a comparative perspective. Journal of European Public Policy 13(3): 456-469.

Woll, C. (2009) Who captures whom? Trade policy lobbying in the European Union. In: D. Coen and J. Richardson (eds.) Lobbying in the European Union. Oxford: Oxford University Press, pp. 268-288.

214 (C) 2012 Macmillan Publishers Ltd. 2047-7414 Interest Groups \& Advocacy Vol. 1, 2, 193-214 